The Parity of the Economic

\title{
Market Place
}

I

Absolute doctrines are always easier to state and perhaps defend than doctrines which have to be limited. The doctrine of complete laissez faire, which is claimed for the area of discussion, is not part of the main tradition of liberalism in the area of economic life. It is not possible on this occasion to outline in detail the proper division of labor between political and economic organization. A few preliminary observations directed to such an outline is all that can be here provided.

1. There is, first of all, the field of taxation, which is, in fact, the field of public expenditures the object of which is redistribution of income. How far such political activity can be carried without ultimately undermining the competitive form of economic organization is indeed an open issue. But it can take a form which will minimize such undermining. Ideally it should take the form of transfers of money income between families. How far this ideal form can be pushed I do not know. It should further take a form which tends to remove the necessity for redistribution, i.e., it should emphasize the goal of greater equality in earning capacity, rather than greater equality in the distribution of results.

The main point I wish to call attention to here is the unnecessary increase of government activity which derives from the implicit assumption that, whenever there is a political decision to make certain expenditures by families compulsory or to assure certain minimum standards of consumption, the organization of the resources involved must also be assigned to the state. The test for the latter should always be whether or not the necessary organization is of a type which can be arranged on a competitive basis. A proper regard for this criterion would, I believe, reduce significantly the area of political decisions without in any way impairing the equalitarian objectives. In fact, an incidental advantage of this principle is that it would clarify the extent to which actual expenditures do, in fact, foster equalitarian objectives and the extent to which they reinforce the inequalities which already exist. The point can perhaps be best illustrated with Mill's observations on the organization of education, made, it is true, with the different objective of preventing the growth of uniformity of ideas:

If the government would make up its mind to require for every child a good education, it might save itself the trouble of providing one. It might leave to parents to obtain the education where and how they pleased, and content itself with helping to pay the school fees of the poorer classes of children, and defraying the entire school expenses of those who have no one to pay them. ${ }^{1}$

1 J. S. Mill, On Liberty.

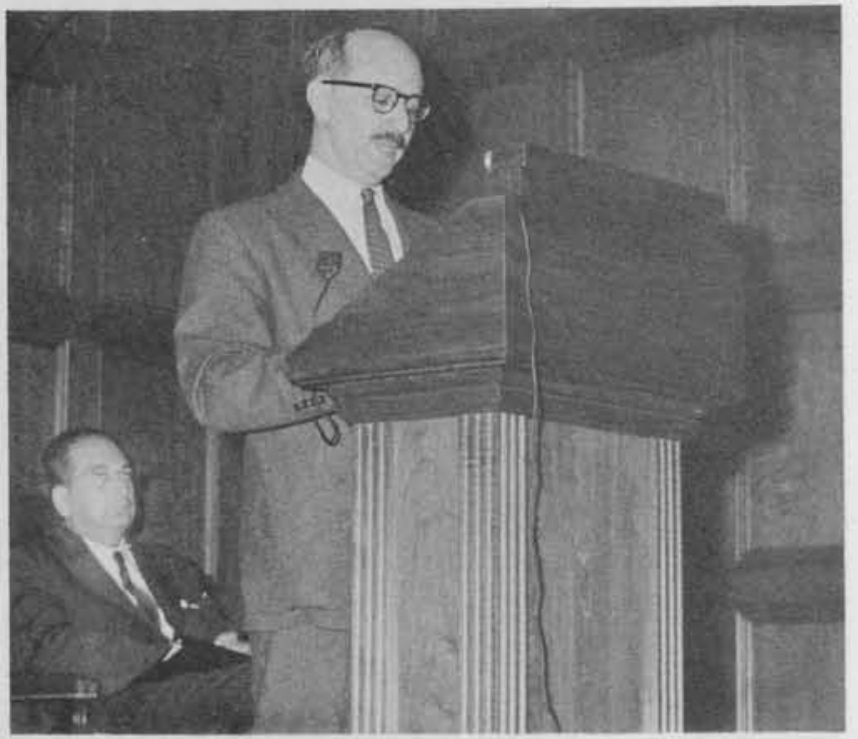

Aaron Director, Professor of Economics in The Law School, presented "The Parity of the Economic Market Place" at the Fiftieth Anniversary Conference on "Freedom and the Law."

2. Laissez faire has never been more than a slogan in defense of the proposition that every extension of state activity should be "examined under a presumption of error." The main tradition of economic liberalism has always assumed a well-established system of law and order designed to harness self-interest to serve the welfare of all. The institution of private property-at least since Hume ${ }^{2}$-has always been defended on this ground. And wherever it seemed that this institution might be modified without subverting the general framework of a competitive society, the tradition has shown a readiness-perhaps exaggerated-to modify this basic institution. But the tradition goes much beyond this. It has always assumed that there were some economic results which cannot be attained at all or attained only in inappropriate amounts if left to the free market.

The tradition has always been hostile to private monopolies whether contrived by enterprise or labor. Inadequate attention to this problem in the earlier period is to be explained by the tacit assumption, which is not without merit, that under neutral rules the market would largely frustrate such contrivances. To the extent that this assumption was shown to be invalid, the tradition has shown a readiness, although not matched by achievement, to formulate positive rules which will do so.

Where economic services can only be provided by monopoly form of organization because of underlying technical conditions, the liberal bias, in our own day at least, is against private exploitation of such monopolies. Fortunately the area does not appear to be yery

2 Cf. David Hume, An Inquiry concerning the Principles of Morals, Sec. III of "Justice." 
extensive. If it were, the conflict between economic freedom and economic efficiency would become significant. The coercive character of monopoly is not altered by transferring it to the state.

3. Reference should also be made to the recognition that a suitable monetary framework cannot be provided by competition and constitutes one of the requisite legal institutions.

4. Having noted these qualifications or "concessions," it is now in point to restate the "presumption of error doctrine." Every qualification is made because of some deficiency in the free-market type of organization. But every deficiency is met by an extension of state activity. It has been well said that "it is not possible to be continually taking steps towards socialism without one day arriving at the goal." ${ }^{3}$ In this respect there is a remarkable similarity between the underlying basis for complete laissez faire in the market for ideas and the market for economic goods and services. The absolute doctrine of the first is defended even though it necessitates the protection of speech which no reasonable man wants or should want to see protected. But there is great wisdom in Justice Douglas' eloquent observation on the danger of encroaching interference:

The Court in this and in other cases places speech under an expanding legislative control. Today a white man stands convicted for protesting in unseemly language against our decisions invalidating restrictive covenants. Tomorrow a Negro will be haled before a court for denouncing lynch law in heated terms. Farm laborers in the West who compete with field hands drifting up from Mexico; whites who feel the pressure of orientals; a minority which finds employment going to members of the dominant religious group-all of these are caught in the mesh of today's decision. ${ }^{4}$

\section{II}

The free market as a desirable method of organizing the intellectual life of the community was urged long before it was advocated as a desirable method of organizing its economic life. The advantage of free exchange of ideas was recognized before that of the voluntary exchange of goods and services in competitive markets. The explanation lies perhaps in the greater complexity of the theory of the market for goods and services, which came only with the actual emergence of a substantial amount of competition.

Moreover, freedom of speech and belief was advocated long before the growth of democracy. Hume and Smith, the leading theorists of the competitive system, were not democrats. With Bentham and James Mill, the argument for freedom merges with that for democracy. And this in a peculiar manner. Leslie Stephen tells us that liberty "means sometimes simply the diminution of the sphere of law and the power of the legislators, or, again, the transference to subjects of the

3 Thomas Mackay (ed.), A Plea for Liberty (3d ed., 1894), p. x.

4 Beauharnais v. Illinois, 343 U.S. 250 at 286. power of legislating, and, therefore, not less control, but control by self-made laws alone." 5 Bentham and James Mill argued for liberty in the second sense on the ground of "responsibility to persons whose interest, whose obvious and recognizable interest, accords with the end in view-good government." And such identity of interest is to be found in "nothing less than the numerical majority." 6 Bentham was not only a great reformer of the law but also a vigorous advocate of liberty in the sense of a diminution of the sphere of law and the power of legislators. The argument for this was the same as that for democracy-interest. "The interest which a man takes in the affairs of another, a member of the sovereignty for example in those of a subject, is not likely to be so great as the interest which either of them takes in his own: still less where that other is a perfect stranger." To this Bentham added the advantage of superior knowledge which is correlated with interest and the very shrewd remark that if the "statesman were better acquainted with the interest of the trader than the trader himself . . . simple information would be sufficient to produce the effect without an exercise of power."7

No conflict between the two types of freedom was at first expected. In point of fact democracy was expected

5 Leslie Stephen, The English Utilitarians, I, 132.

6 J. S. Mill, "On Bentham," in Dissertations and Discussions, I, 377.

7 W. Stark, Jeremy Bentham's Economic Writings, I, 229-31.

(Continued on page 19)

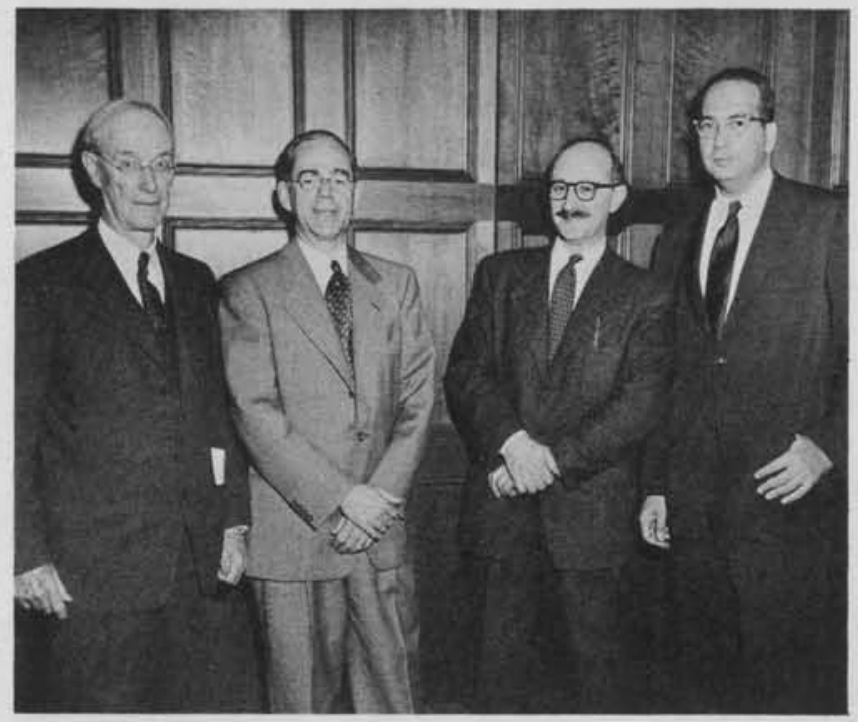

Participating in the morning session on "Freedom in the Two Market Places" were (left to right) Alexander Meiklejohn, former president, Amherst College, and former chairman of the Experimental College of the University of Wisconsin, who spoke on "The Priority of the Market Place of Ideas"; Wilber G. Katz, James Parker Hall Professor of Law, who presided; Professor Director; and Paul A. Freund, Professor of Law, Harvard University, whose paper was entitled, "Competing Freedoms in American Constitutional Law." 


\section{The Economic Market Place (Continued from page 7)}

to reinforce the other type of freedom. Any Englishman at the end of the eighteenth century who, says Leslie Stephen, the historian of utilitarianism, demanded more power for the people "always took for granted their power would be used to diminish the activity of the sovereign power; that there would be less government and therefore less jobbery, less interference with free speech and free action, and smaller perquisites to be bestowed in return for the necessary services. The people would use their authority to tie the hands of the rulers, and limit them strictly to their proper and narrow functions."

No conflict between the two types of freedom did, in fact, arise for a considerable period of time, and, when John Stuart Mill wrote the celebrated essay $O n$ Liberty, it was not to encroachment on individual liberty through legislation that he directed his eloquence but to the tyranny of public opinion. This was also the main theme of Tocqueville's famous book which significantly strengthened Mill's own views on the dangers of democracy. ${ }^{9}$

The subsequent decline of the attachment to individualism as dogma and the gradual replacement of freedom in economic affairs by collectivist (i.e., political)

8 Op. cit., p. 132.

${ }^{9} \mathrm{Cf}$. Mill's review on Democracy in America (Dissertations and Discussions, II, 1-83). 
forms of organization were admirably traced by Dicey first at the end of the century and again in $1914 .^{10}$ The further extension of collectivism in our time substantially enhances the reputation of Dicey as a prophet. Putting to one side that part of intellectual opinion which has repudiated the attachment both to civil liberty and to economic freedom, we note the marked divergence between the attachment to liberty as participation in government and the repudiation of liberty as freedom from restraint through government direction of economic life. In the former I include the attachment to free speech, the only area where laissez faire is still respectable.

Bearing in mind the danger of generalization without empirical investigation, it may nevertheless be asserted with some confidence that among intellectuals there is an inverse correlation between the appreciation of the merits of civil liberty-including freedom of speechand the merits of economic freedom. I believe this generalization will hold even after the exclusion from the evidence of that group whose attachment to civil liberty is limited to the transition from the capitalist hell to the authoritarian heaven. Lacking empirical data for this generalization, I must resort to intellectual pride as partial proof. Dissent from the generalization implies either that intellectual discussion is without influence in the formation of policy or that intellectual opinion is always two generations behind the times.

Some evidence is readily available. Justice Douglas has told us:

Free speech, free press, free exercize of religion are placed separate and apart; they are above and beyond the police powers; they are not subject to regulation in the manner of factories, slums, apartment houses, production of oil and the like. ${ }^{11}$

And Justice Black tells us with eloquent brevity that, when it comes to the fixation of prices of natural gas which goes into interstate commerce, "the alleged federal constitutional questions are frivolous." ${ }^{12} \mathrm{I}$ am aware that the preferred position accorded to free trade in ideas is based on constitutional considerations, with which I am not concerned. But I believe that the preference goes beyond such considerations. Justice Black tells us not only that "my own belief is that no legislature is charged with the duty or vested with the power to decide what public issues Americans can discuss." He tells us at the same time that "in a free country that is the individual's choice not the state's." ${ }^{13}$ Our distinguished visitor tells us not only that the Constitution draws a distinction between the liberty of owning property and freedom of discussion; he warns us also that, by confusing the two, "we are in constant

10 A. V. Dicey, Law and Public Opinion in England (2d ed., 1914).

11 Beauharnais v. Illinois, 343 U.S. 250 at 286.

12 Cities Service Co. v. Peerless Co., 340 U.S. 179 at 189.

13 Beauharnais v. Illinois, 343 U.S. 250 at 270. 
danger of giving to a man's possessions the same dignity, the same status, as we give to the man himself."14 I hold that this dichotomy is a doubtful one, and I turn to this aspect of the problem.

\section{III}

A superficial explanation for the preference for free speech among intellectuals runs in terms of vested interests. Everyone tends to magnify the importance of his own occupation and to minimize that of his neighbor. Intellectuals are engaged in the pursuit of truth, while others are merely engaged in earning a livelihood. One follows a profession, usually a learned one, while the other follows a trade or a business. To cite a trifling example: For every opinion voiced in England against restriction of ordinary imports, there must be a hundred against restriction on foreign travel. Objective evaluation of the two restrictions would recognize that they differ only in that one involves bringing the goods to the consumer, while the other involves shipping the consumer to the goods. Intellectuals, on the other hand, see one restriction as interference with culture and the other as mere exclusion of cheap American movies.

Such an attitude does not accord with a proper respect for the ordinary activities of the bulk of mankind. Short of a revolution in tastes which would make people want much less than they now have of material well-being, or a revolution in technology while keeping present material wants constant, neither of which can be expected, most men will for the foreseeable future have to devote a considerable fraction of their active life to economic activity. For these people freedom of choice as owners of resources in choosing, within available and continually changing opportunities, areas of employment, investment, and consumption is fully as important as freedom of discussion and participation in government. The former freedom is at least important for those who wish to exercise such freedom.

It is perhaps of such people and of such activities that Tocqueville wrote:

The principle of enlightened self-interest is not a lofty one, but it is clear and sure. It does not aim at mighty objects, but it attains without impractical efforts, all those at which it aims. As it lies within the reach of all capacities, everyone can without difficulty apprehend and retain it....

The doctrine of enlightened self-interest produces no great acts of self-sacrifice, but it suggests daily small acts of selfdenial. By itself it cannot suffice to make a virtuous man, but it disciplines a multitude of citizens in habits of regularity, temperance, moderation, foresight, self-command: and if it does not at once lead men to virtue by their will, it draws them gradually in that direction by their habits. ${ }^{15}$

The preference for the free market in ideas stems also from an undue emphasis on the definition of democ-

${ }^{14}$ Alexander Meiklejohn, Free Speech and lts Relation to Self-government, p. 2.

15 Democracy in America, II, 122-23.

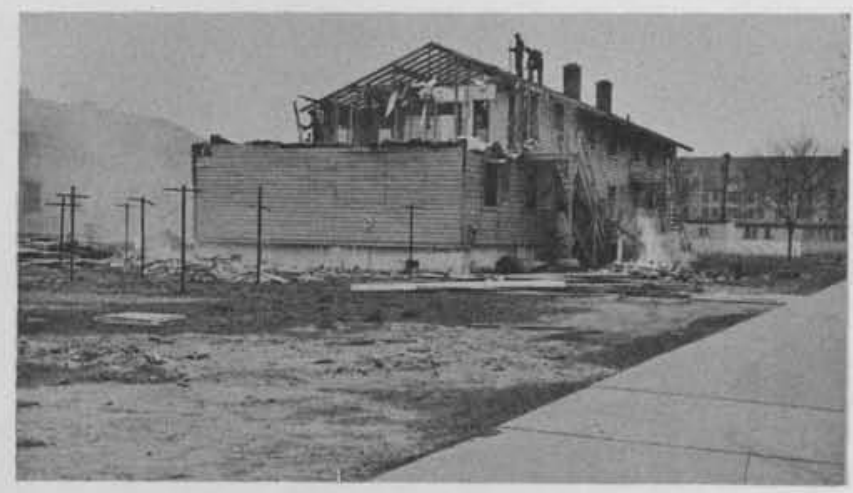

The wrecking crews are at work on the University of Chicago campus preparing the ground for the new home of the American Bar Association.

racy as government by discussion or consensus and neglect of the older description of democracy as government by majority rule. We have no better alternative for making political decisions. But decisions are made by consensus in the sense that all participated in making them, and those who do not like the decisions are willing to accept them because of their initial preference for this method of making them. This does not alter the coercive character of government. "The minority gives way not because it is convinced that it is wrong, but because it is convinced that it is a minority." ${ }^{16}$ The consent in question is only moderately different from Hume's conception of consent which obtains under all forms of government. And this suggests the wisdom of the older persuasion that coercion is increased as the area of political decision is enlarged.

It is only under a system of voluntary exchange that freedom is meaningful. It is then possible to choose between alternative voluntary association. The choice which one has in moving from one coercive authority to another is very limited in any event and is further narrowed as economic affairs are increasingly converted into political discussion and decision. It is surely no accident that mobility of people between states was greater when there was a more complete division of labor between political and economic institutions. The choice for members of a minority which does not consent to socialist institutions, even assuming that other socialist societies will accept them, is that of departing with bare feet. And such restriction is described as regulation of possessions or property rather than of men.

The priority accorded to the free market for ideas as against the free market for economic affairs is derived also from an undue importance attached to discussion as a method of solving problems. In consequence there is inadequate appreciation of the substantial merits of the impersonal character of the market when it is competitive. The election is sufficiently recent to make superfluous an elaborate statement of the foolishness which passes for discussion when specific

${ }^{16} \mathrm{~J}$. F. Stephen, Liberty, Equality and Fraternity, p. 28. 
and important issues of policy such as trade between nations, fixing rents of houses, or subsidies to agriculture are made the subject of collective decision. Skepticism regarding the possibilities of solving problems by political decisions after discussion is not confined to those with a bias for the advantages of the impersonal market. It is in fact shared by those who wish to maximize the area of such decisions. This must be the explanation for the results of the recent election which runs in terms of the effectiveness of advertising and radio and television entertainment against the party which "talked sense to the American people." Professor Cooley, a not unsympathetic student of democratic institutions, has emphasized the great amount of "nonsense" which passed for discussion when such issues as the silver question were made the subject of political decisions. And he finds the saving feature of democracy in the skill of the ordinary man in choosing between persons. ${ }^{17}$ This in turn emphasizes the large element of discretionary authority inherent in increasing the scope of political authority over economic organization.

Finally, Professor Knight, who has explored the limitations of the impersonal voluntary exchange system of organization with greater subtlety than any critic of that system, has in turn warned us of the limitations of discussion:

Genuine, purely intellectual discussion is rare in modern society, even in intellectual and academic circles, and is approximated only in very small and essentially casual groups. On the larger scale, what passes for discussion is mostly argumentation or debate. The intellectual interest is largely subordinate to entertainment, i.e. entertaining and being entertained, or the immediate interest of the active parties centers chiefly in dominance, victory, instructing others, or persuading rather than convincing, and not in the impartial quest of truth. ${ }^{18}$

The traditional defense of the free market as a method of organizing economic life has been utilitarian or instrumental. This emphasizes the consequent efficiency with which resources are used to achieve given ends. It derives its emphasis from the economist's desire to be scientific. The traditional defense of the free market in ideas has in the main also been utilitarian. Thus it plays an important role in Mill's defense of freedom of discussion. It has been challenged in both areas and more extensively in the sphere of economic matters. An empirical test of efficiency in the absence of experiment with alternative forms of organization is not readily available. The historical evidence is stronger-at any rate, less ambiguous-in the economic area. The short period of liberalism has been accompanied by as much material progress as took place in all prior times. But the evidence has not been persuasive. It is always easy to contrast the observed deficiencies with

17 C. H. Cooley, Social Organization, pp. 142-43.

18 F. H. Knight, Freedom and Reform, p. 349. the unknown advantages. And cognizance of deficiencies tends-rightly-to grow with material progress. Very recent experience with alternative forms of organization has again strengthened the efficiency argument. This is all to the good: "The common man or average family has a far greater stake in the size of our aggregate income than in any possible redistribution of income." ${ }^{19}$ Current concern over the effect of taxation on incentives also illustrates the revived interest in efficiency. But I have tried to emphasize the importance of the free market as an end in itself, as an important aspect of freedom to choose between alternatives. While not always explicit, I believe it has always been implicit in the attachment of the great economists to the liberal tradition. In this context freedom means more than discussion and participation in government. It means responsibility, change, adventure, departure from accepted ways of doing things. It means freedom to choose one's ends as well as means for attaining them. In Leslie Stephen's phrase, it means "energy, self-reliance, and independence, a strong conviction that a man's fate should depend upon his own character and conduct." ${ }^{20}$ It is broader than Milton's dictum: "The whole freedom of man consists either in spiritual or civil liberty."

More recently with the spread of authoritarian regimes which have destroyed both economic and intellectual freedom, the instrumental character of the free economic market in an entirely new context has received substantial recognition. This is the argument that noneconomic freedom cannot flourish when the division of labor between voluntary organization and the coercive state is destroyed. Again the argument is not altogether new. Mill, whose defense of the free market was mainly in terms of efficiency, nevertheless added that if the "industries, the universities and the public charities, were all of them branches of the government; . . . if the employees of all these different enterprises were appointed and paid by the government, and looked to the government for every rise in life; not all the freedom of the press and popular constitution of the legislature would make this or any other country free otherwise than in name." ${ }^{21}$

In this respect the political economists have shown better insight into the basis of all freedom than the proponents of the priority of the market place for ideas. The latter must of necessity rely on exhortation and on the fragile support of self-denying ordinances in constitutions. The former, on the other hand, have grasped the significance of institutional arrangement which foster centers of resistance against the encroaching power of coercive organization. Failure to appreciate this essential method of protection of freedom among students of the law who minimize the importance of the free eco-

19 Henry Simons, Economic Policy for a Free Society, pp. 5-6.

20 Op. cit., p. 131.

21 On Liberty. 
nomic market is especially striking. In their own field they fully recognize the great significance of legal institutions-procedure-as against the substantive content of law in protecting the liberty of the subject.

The issue is no longer one of the general theory of the essential character of major economic decisions made by political organizations, which involves broad delegation of power to experts who cannot be disciplined by those for whom they act. As individual freedom is being challenged because we are no longer indifferent to diversity of views, we get an indication of what may happen when the state becomes the principal employer or determines the conditions of employment. The privilege against self-incrimination may not be an important protection of freedom. But any legal protection of this general type will become an empty piece of ceremonial apparatus when its exercise and protection is accompanied by the loss of one's livelihood. This may increase our esteem for martyrdom, but martyrs are not always rewarded in this world.

We can learn much in this context from the acute observations of a recent comprehensive review of the privilege against self-incrimination. Without access to books and records, we are told: "The enforcement of complicated regulation would break down and would involve additional costs not easily met in a period when the government is assuming staggering commitments. It is not surprising that a majority of the Supreme Court was convinced that the application of the privilege to required records is a luxury which a welfare-state cannot afford." ${ }^{22}$ Economists cannot distinguish between luxuries and necessities; other necessities may become mere luxuries which the welfare state cannot afford. Courts cannot provide satisfactory alternative areas of employment and promotion.

It is not essential to demonstrate that there is only one road to serfdom or that a particular road must inevitably lead to a specified destination. Some institutions are more flexible than others. We must choose those which minimize the risks of undesirable consequences. 